\title{
Review on Epidemiology of Camel Mange Mites
}

\author{
Jarso $\mathrm{D}^{1}$, Birhanu $\mathbf{S}^{1}$ and Wubishet $\mathrm{Z}^{* 2}$ \\ ${ }^{1}$ Haramaya University College of Veterinary Medicine, Haramaya, Ethiopia \\ ${ }^{2}$ Oromia Pastoralist Area Development Commission Yabello Regional Veterinary Laboratory, Ethiopia
}

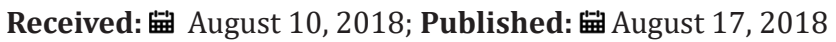

*Corresponding author: Wubishet Z, Oromia Pastoralist Area Development Commission Yabello Regional Veterinary Laboratory, Ethiopia

\begin{abstract}
We reviewed the paper to document the status of mange mite in camel raising arid and semi-arid areas of the world. Different published research papers and books from 1980 to 2018 on ecto-parasites of the camel (including mange mites) were reviewed. Published papers were obtained online by web browsing and books from university library. Mange is caused by different species of Sarcoptus, Psoroptus, Chorioptus and Demodex in camels. This parasite is important parasite in camel raising area of the world. High infestations are noted during rainy season, at young and old age, camel with poor body condition, and in large herds. Relatively, Sarcoptic mange caused by Sarcoptes scabieivarcameli is considered to be one of the most and economically important zoonotic and epizootic diseases with spread capacity among animals via direct physical contact with infested animal and indirectly through fomites.It is also one of the most prevalent type of camel mange. Occurrence of the disease is mostly associated with poor management and a mingling of diseased camels with healthy ones.

Camel mange mite infestation usually starts from head region and then extends to the neck and other areas of the body with thin skin. The scabies may spread to the whole body within a period of one month. In conclusion, Camels are important animal raised in arid semi-arid area of area of the world. Even though it provides many advantages to people in marginal areas; the camel has received very little attention as compared to other species of domesticated animals. For this reason, camels are affected by several diseases including mange mites. In developing countries like Ethiopia Pastoralists in lowlands area shifting their livestock production from cattle to camel due to recurrent drought and adaptation capacity of the camel especially in East Africa. Therefore, camel raising communities need to treat their camels regularly by anti-mange mite drugs; and governmental and nongovernmental organization working on livestock health need to give attention for camels in camel diseases research and their management. In addition, pastoralists need to separate infested camels from health ones, cleaning fomites before and after used, and treating herds when one or more camel show clinical sign.
\end{abstract}

Keywords: Camel; Epidemiology; Mange mites

\section{Introduction}

Camels are versatile animal species in ensuring food security and fulfilling the livelihood priorities of pastoral households in the arid and semi-arid areas of Ethiopia. They provide pastoral communities with income, food supply, transportation services and other social benefit s such as prestige (social status), ceremonial uses insurance and risk buffering options [1]. The ability of the camel to survive in harsh areas of the world, its endurance in prolonged drought, and above all its high potential to convert the scanty resources of the desert into milk and meat makes them more important to the pastoralists [2]. Even though camel provides this benefit to people, camel has received very little attention as compared to other species of domesticated animals in many area of the world including Sudan, Somalia and Ethiopia where large camel population is recorded [3].

Sarcoptic mange in one humped-camels (Camelus dromedarius) caused by Sarcoptes scabieivarcameli is considered to be one of the most and economically important zoonotic and epizootic diseases that can spread among animals via direct physical contact with infested animal and indirectly through fomites (ropes, blankets and saddlery) especially in tropical and subtropical areas [47].Occurrence of the disease is mostly associated with poor management and a mingling of diseased camels with healthy one's $[8,9]$. Sarcoptic mange is one of the most prevalent type of camel mange. Recently, attempts have been made to understand mange molecular epidemiology using genetic tools to differentiate between isolates from different hosts and geographical regions $[10,11]$. The epidemiology of mange is still not well understood and seems to differ between animal species and areas of the world. Therefore, the objectives of this reviewis to collate information onprevalence of mange mite among different countries where Camelus dromedariusis kept and also to explore different risk factors associated with the spread of mange mites in camels.

\section{Epidemiology of Camel Mange Etiology of Camel Mange}

Mange is a highly contagious skin disease caused by one or a combination of several species of mite [12]. These include species from the genera Sarcoptus, Psoroptus, Chorioptus and Demodex. Some species are more widely distributed globally than others. 


\section{Sarcoptic Mange}

Sarcoptic mange in camels caused by Sarcoptesscabieivarcameli is considered to be one constagious of the most serious, zoonotic [13] and debilitating disease affecting both dromedary (Arabian and bactrian camels) and Ilamas [14]. It is regarded as one of the most prevalent camel diseases [14].

\section{Psoroptes Mange}

It was shown that Psoroptesssp isolates of different phenotypes, hosts andgeographic origins are nonspecific [15-17] recorded the only documented case of psoroptic mange in dromedaries and in bactrians in Mongolia.But are less commonly found on camelids than S. scabiei.

\section{Chorioptes Mange}

Infestation with Chorioptesis most probably rare in camels. It has been reported on a Bactrian camel [14] and in the Netherlands on one llama, three alpacas and two camels, one of which had foot mange [18].

\section{Demodex Mange}

The preferred site of the burrowing mite of the genus Demodex is at the hair follicles and sebaceous glands of the skin. These follicular mites mainly lived as commensals in the skin. In some animals, these mites may causemange, causing economic loss [19]. The mite is most probably transmitted from the dam to the offspring during nursing. Demodexspp is found inall domestic mammals and humans worldwide. They havebeen reported on dromedaries in Iran where the eyelids of $15 \%$ of the camels were infested [20]. There was no evidence of any secondary bacterial infection in the investigated camels, nor were there any significant histological changes other than distention of the hair follicle. Demodex spp,was isolated from camels exhibiting mange on a ranch in Kenya [21].

\section{Epidemiology of Camel Mange}

Mange mites are ubiquitous ectoparasite that infects more than 100 species of mammals worldwide [10,21]. It affects both domestic animals and humans, but also wild life [21,22]. In humans it is known to cause considerable morbidity in a number of different countries [23,24]. Mange was regarded as a major disease during early19 century when large trading camel caravans were common with the decline of the large trading caravans and the camel-keeping tribes' conditions are seldom as favourable for the spread of the disease as when large numbers of dromedaries congregated at a given site with caravans continually arriving and departing. Such animals were usually in poor condition and fatigued by long journeys; their feeding was poor and the hygienic conditions unsatisfactory. Epidemics can be caused by contagion from a single case of scabies in crowded living conditions [25]. Sarcoptic mange may lead to considerable economic losses in domestic animalswith repercussions for the animal trade. It also has devastating consequences for wild animals, above all in isolated populations a situation that is worsening due to the limitations of available chemotherapy [26-29]. It is prevalent different parts of the world were camels raised.

\section{Risk factor of Camel Mange}

Mange was a term used to describe mite-associated skin disease in livestock. The occurrence of mange mite in dromedary camels depending up on the following factors. In wet season camel mange mites is higher relative to dry season [1]. Prevalence of camel mange on age of camel's different author have used different age group to determine which age group more affected; some author said young and old animal more affected due to decreased immunity when we compared with adult one, which have high immunity than both [30-37]. On prevalence of mange on sex of camel's different authors had different opinions; some stated that camels male is more affected by mange than female [32]. Others however, stated female are more affected than male [1,38-40]. This may be associated with some hormonal influences; the higher level of prolactin and progesterone hormones could make the females more susceptible to any infection [41]. Additionally, pregnancy and lactation stress could also aggravate the susceptibility of the female camels to infections. Furthermore, the breeding behavior of mange infested males could also be attributed to the transfer of disease to a number of females. In contrast these some researchers observed no relationship between infestation with mange and sex animals [35].

Poor body condition was recorded in camels infested with mange mite. This result may be attributed to sever allergy and itching due to outcome of histamine liberated from damaged body cells which are compelling allergens [42]. In addition, the higher prevalence in poor body conditioned animals might be due to trypnosomosis, worm burden and poor nutrition status which can act as predisposing factors of sarcoptic mange infestation as described [5]. In researches done in Ethiopia, majority of the findings attribute to higher prevalence in animal with poor body condition, these results were due to cross-sectional epidemiological studies findings [31,37]. Mites can be transmitted by contact beddings and tree trunks can be other sources of transmission, camels rub themselves on tree trunks leaving the mites where the next animal may pick [32]. Since dairy camels are usually kept indoors and in close proximity, this contact favors transmission of the causative agent of mange and hence easy establishment of the disease in the herd. As herd size increases the prevalence of S. scabie var. cameli also increased significantly [43].

\section{Economic importance of Camel Mange}

The economic values of mange infested animal emanate from decreased body weight, expense of therapy, deterioration of skin due to perforation of the skin and intense pruritus as skin lesions may cover almost the entire body, and occasional mortalities in untreated and young animals [4]. In addition, mange mite has enormous zoonotic and public health significance [4,5]. Moreover, mange can harshly decrease the welfare of milking animals as reducing the vitality and increased susceptibility to other diseases as a result of secondary bacterial infection. It can abridge milk production and disserve milking procedure as a result of uneasiness of infested animals [32]. During development of mange, itchiness distracts the animals from eating so that they often become 
emaciated. The specific lesions are confined to the integument and comprise hyperkeratosis, anemia, general loss of productivity and body weight [44].

\section{Clinical Sign, Diagnosis and Treatment of Camel Mange}

Camel mange mostly diagnosed base on it is Symptoms. Which included intense pruritis, exudative dermatitis, parakeratotic scaly crust formation, alopecia and dark thickened skin [45]. Fissures developed in the crust and underlying epidermis resulting in hemorrhages. Emaciation, debilitation, anemia and subcutaneous edema were common signs in mange camels [46, 47]. The hyperkeratotic stage is easy to recognize by large areas devoid of hair, with thickened skin and folds around the joints, affecting the hind limbs and neck. Ivermectin subcutaneous injection can cure the mange mites in camel [5]. The post treatment hematological and biochemical values were within the normal wrinkling, falling of scabs, skin folds becoming less and subsequent appearance of fresh shiny skin with glossy hair 1-3 mm long prior to second treatment absence of tissue swelling because of injections, disappearance of clinical signs of itching with parasitological cure noticed by 56 days[48].

\section{Conclusion}

Camel mange is economically important contagious camel disease that impact on their productivity and health. The overall prevalence of mange mite infestation varies from country to country it was $2.3 \%-97.4 \%$. S.scabiei, Demodex spp, Psoroptes spp and Chorioptes spp being mite that was found from different country where studies were conducted. The most prevalent species were S.scabiei followed by Demodex spp. Origin, body condition, season, herd size, sex, age, parts of camel body were considered significant risk factors associated with the prevalence of mange mite infestation. Therefore, training should be given for camel raising communities on parasite control and camel management system to reduce mange mites effected in camel production.

\section{References}

1. Megersa B (2014) Major Diseases of Camel Calves in Borana of Southern Ethiopia. African Journal of Basic \& Applied Sciences 6 (6): 159-165.

2. Wosene A (1991) Traditional husbandry practices and major health problems of camels in the Ogaden (Ethiopia). Nomadic peoples p. 21-30.

3. Atif E, Adil S (2016) Status of camel research and development in Sudan: International conference on camel research, Jijiga Town, Ethiopia p. 2729.

4. Singh VR (2005) Parasitic Zoonosis (1 $1^{\text {st }}$ Edn.), Poimer publication Jaipur India for Parasitology 29: 759-766.

5. Parsani HR, Veer Singh, Momin RR (2008) Common Parasitic Diseases of Camel. Veterinary World 1(10): 317-318.

6. Wilson RT (2008) Perceptions and problems of disease in the onehumped camel in southern Africa in the late 19 th and early $20^{\text {th }}$ centuries: historical review. Journal of the South African Veterinary Association 79(2): 58-61.

7. Awol N, Skiros, Y Tsegaye, M Ali, Hadush B (2014) Study on mange mite of camel in Raya Azebo district, northern Ethiopia. Veterinary Research Forum 5(1): 61-64.

8. Rickard D (1987) Camel mange, Review Scientific. Technical off International. Epizootic 1987 6(2): 475- 477.
9. Abdel Rehman MB, Osman AY, Hunter AG (2001) Parasites of the onehumped camel (Camelusdromedarius) in the Sudan: A review. The Sudan Journal Veterinary Research 17: 1-13.

10. Alasaad S, Oleaga Á, Casais R, Rossi L, Min AM, et al. (2011) Temporal stability in the genetic structure of Sarcoptesscabiei under the hosttaxon law: empirical evidences from wildlife-derived Sarcoptes mite in Asturias, Spain. Parasites and vectors 4(1): 151.

11. Rasero R, Rossi L, Soglia D, Maione S, Sacchi P, (2010) Host taxon-derived Sarcoptes mite in Eropean wild animals revealed by microsatellite markers.Biological Conservation 143(5): 1269-1277.

12. Muller GH, Kirk RW, Scott DW (1989) Small animal dermatology, (4 $4^{\text {th }}$ Edition) WB Saunders Company, Philadelphia, Pennsylvania 1,007.

13. Singh V, Momin RR, Parsani HR (2001) Therapeutic efficacy of doramectinagainstsarcoptic mange in camel.Journal Veterinary Parasitology 15: 75-76.

14. Higgins A (1986) Commonectoparasites of the camel and their control. In: A.J. Higgins (ed.): The Camel in Health and Disease. Bailli and re Tindall and Cox London.

15. Werner G, Porsch G, Ilchmann G, Hiepe T (1989) Exploratory studies on the efficacy of Bayticol Pour on in sheep, cattle and camels in the People's Republic of Mongolia. Veteinaer Medizinische Nachrischten. Review 60: 40- 42.

16. Zahler M, Essig A, Gothe R, Rinder H (1998) Genetic evidence suggests that Psoroptes isolates of different phenotypes, hosts and geographic origins are conspecific.International Journal for Parasitology 28(11): 1713-1719.

17. Gabaj MM, Beesley WN, Awan MAQ (1992) A survey of mites on farm animals in Libya.Annals of Tropical Medicine and Parasitology 86(5): 537-542.

18. Cremers h (1984) The incidence of chorioptes-bovis (acarina, psoroptidae) in domesticated ungulates. Intropical and geographical medicine 36(1): 105-105.

19. Wernery U, Kaaden O (2002) Infectious diseases in camelids, 2nd revised and enlarged edition. Blackwell Wissenschafts-Verlag $\mathrm{GmbH}$ Kurfiirstendamm pp. 57, 10707

20. Alasaad S, Soglia D, Sarasa M, Soriguer RC, Pérez JM, et al. (2008) Skinscale genetic structure of Sarcoptesscabiei populations from individual hosts: empirical evidence from Iberian ibex-derived mites.Parasitology research 104(1): 101-105.

21. Bomstein S (1995) Skin diseases of camels in camel keeping in Kenya. Ed. Evans, JO, S Piers Simpkin and DJ Atkins. Range ManugmentH and book of Kenya 3(8): 7-13.

22. Kahn CM, Line S, Allen DG, Anderson DP, Jeffcoh LB (2005) Acariasis mite infestation.In the Merck Veterinary Manual ( $9^{\text {th }}$ Edn.). Published by Merck and Co Inc, Whitehouse Station, New Jersey, USA, pp. 742-749.

23. Heukelbach J, Feldmeier H Scabies (2006) The Lancet 367(9524): 17671774.

24. Walton SF, Dougall A, Pizzutto S, Holt D, Taplin D, et al. (2004) Genetic epidemiology of Sarcoptesscabiei (Acari: Sarcoptidae) in northern Australia. International journal for parasitology 34(7): 839-849.

25. Obasanjo 00, Wu P, Conlon M, Karanfil LV, Pryor P, et al. (2001) Outbreak of Scabies in a Teaching Hospital Lessons Learned.Infection Control and Hospital Epidemiology 22(01): 13-18.

26. Pence DB, Ueckermann E (2002) Sarcoptic manage in wildlife. Revuescientifiqueet technique (International Office of Epizootics) 21(2): 385-398.

27. Dagleish MP, Ali Q Powell RK, Butz D, Woodford MH (2007) Fatal Sarcoptesscabiei infection of blue sheep (Pseudoisnayaur) in Pakistan. Journal of Wildlife Diseases 43(3): 512-517.

28. Alasaad S, Schuster RK, Gakuya F, Theneyan M, Jowers MJ, et al. (2012) Applicability of molecular markers to determine parasitic infection 
origins in the animal trade: a case study from Sarcoptes mites in wildebeest.Forensic science, medicine, and pathology 8(3): 280-28.

29. Bradberry SM, Cage SA, Proudfoot AT, Vale JA (2005) Poisoning due to pyrethroids. Toxicological reviews 24(2): 93-106.

30. Saber K, Ahmed AR (2015) Sarcoptic mange of camel in upper Egypt: Prevalence, risk assessment, and control measures. Journal Advance. Veterinary Animal.Research 2(4): 410-417.

31. Aboma R, Nesibu A, Birhanu H, Yisehak T, Teshale S (2014) Internal and external parasites of camels (Camelusdromedarius) slaughtered at Addis Ababa Abattoir, Ethiopia. Journal of Veterinary Medicine and Animal Health 6(7): 30-30.

32. Megersa B, Damena A, Bekele J, Adane B, Sheferaw D (2012) Ticks and mange mites infesting camels of Boran pastoral areas and the associated risk factors, southern Ethiopia. Journal of Veterinary Medicine and Animal Health 4(5): 71-77.

33. Driot C, Kamili A, Bengoumi M, Faye B, Delverdier M, Tligui N (2011) Study on the epidemiology and histopathology of sarcoptic mange and ringworm in the one-humped camel in South of Morocco.Journal of Camel Practice and Research 18(1): 107-114.

34. Zahid, A Maqbool, S Anjum, K Ashraf, N Ahmad, et al. (2015) Prevalence of sarcopticmange in camels in Punjab, Pakistan.The Journal of Animal and Plant Sciences 25(5): 1259-1263.

35. Hussain MH, Habasha FG, Faraj MK (2012) Demodectic mange in Iraqi camels. AL-Qadisiya Journal of Veterinary Medicine Science; 11(1): 1-5.

36. Dinka A, Eyerusalem B, Yacob HT (2010) A study on major ectoparasites of camel in and around Dire Dawa, Eastern Ethiopia.Rev Med Vet 161(11): 498-501.

37. Nesibu A, Semere K, Yisehak T, Mohammed A, Birhanu H (2014) Study on mange mite of camel in Raya-Azebo district, northern Ethiopia. Veterinary Research Forum 5 (1): 61-64.

38. Gebrehiwet T (1997) An assessment of the efficacy of deltamethrin with $\mathrm{HCH}$ for the treatment of sarcoptic mange in camels. Tropical.Animal. Health Production 29(1): 33-34.

\section{ISSN: 2574-1241}

DOI: $10.26717 / B J S T R .2018 .08 .001605$

Wubishet Z. Biomed J Sci \& Tech Res

(C) (P) This work is licensed under Creative

Submission Link: https://biomedres.us/submit-manuscript.php
39. Ahmed AR (2014) Epidemiological studies on parasitic infestations in camels (camelusdromedaries) in Egypt. European Journal of Environmental Ecology 1(1): 16-20.

40. Ashraf S, Chaudhry HR, Chaudhry M, Iqbal Z, Ali M, et al. (2014) Prevalence of common diseases in camels of Cholistan desert, Pakistan. Biology 2(4): 49-52.

41. Lloyd S (1983) Effect of pregnancy and lactation upon infection. Veterinary Immunology and Immunopathology 4(1-2): 153-176.

42. Fowler ME, Bravo PW (2010) Digestive system. Medicine and Surgery of Camelids ( $3^{\text {rd }}$ Edn.), pp. 351-402.

43. Teka F, Petros A, Ziad A, Bahar M (2015) Epidemiological and therapeutic studies of camel mange in Fafan zone, Eastern Ethiopia. Parasites and Vectors 8: 612.

44. Higgins AJ (1983) Observations on the diseases of the Arabian camel (Camelusdromedarius) and their control. A review Veterinary Bulletin (UK).

45. Kettle DS (1995) Medical and Veterinary Entomology, Second Edition. CAB International, Wallingford, Oxon OX10 8DE, UK.

46. Amer A, Abou El Ela, A, Ratib H (2006) Some Hemato-biochemical studies on Sarcoptic mange infested camels before and after treatment by doramectin at Assiut governorate. Proceedings of the international scientific conference on camels p. 9-11.

47. Kumar D, Raaisinghani P, Manohar GS (1992) Sarcoptic mange in camels: A review. Proceedings of the 1st International CamelConference, Feb. 2-6, Newmarket Press, UK, p. 27-32.

48. Premalatha N, Jayathangaraj MG, Senthilkumar K, Senthilvel K, Vengadabady N, et al. (2010) Strategic treatment of scabies in captive camels (Camelusdromedarius). Tamilnadu Journal of Veterinary and Animal Sciences 6(4): 188-190.

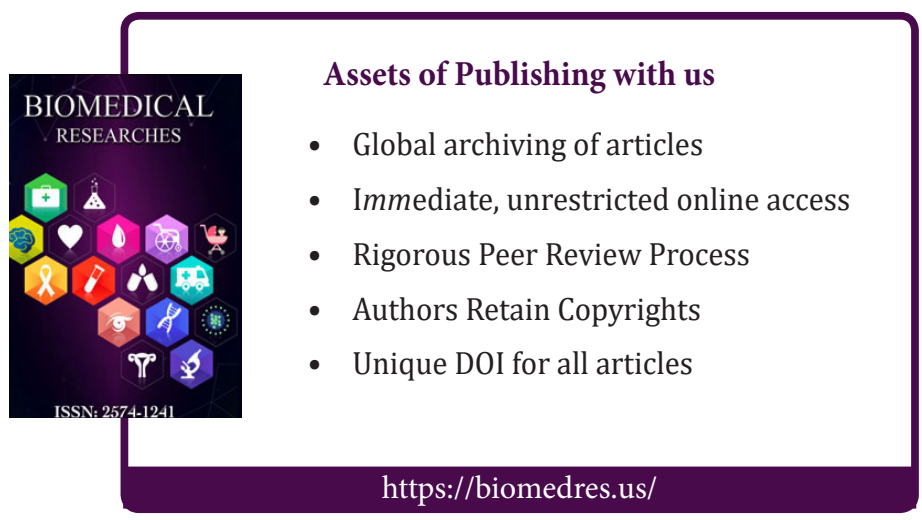

Cite this article: Jarso D, Birhanu S, Wubishet Z. Review on Epidemiology of Camel Mange Mites. Biomed J Sci\&Tech Res 8(1)- 2018. BJSTR 